\title{
COMPARISON OF SEISMIC PERFORMANCE OF VARIOUS MID RISE BUILDINGS WITH DIFFERENT PLAN CONFIGURATIONS
}

\author{
Rosmydavis $^{1}$, Srinidhilakshmish Kumar ${ }^{2}$ \\ ${ }^{1} P$ G student, Department of Civil Engineering, Christ University Faculty of Engineering, Bengaluru, India \\ ${ }^{2}$ Assistant Professor, Department of Civil Engineering, Christ University Faculty of Engineering, Bengaluru, India
}

\begin{abstract}
Most of the structures are vulnerable to lateral loads, especially to seismic loads which are dynamic in nature and highly unpredictable. The vulnerability increases if the buildings are asymmetric and located in urban areas where multi-storey construction is in demand. The current research is undertaken to analyze the multi storey buildings with various plan configuration that are commonly found in urban areas assuming them to be in seismic zone IV. The surface area of the building plan configurations considered are kept constant to ensure that the overall cost of buildings remains same. The buildings are analysed using finite element software ETABS. The models are analysed using equivalent static method and response spectrum method. Relevant Indian standard codes are used while modelling and analyzing. The parameters considered for comparison are fundamental time period, base shear, storey drift and lateral displacement. The number of modes is decided based on the values of modal mass participation factor and rotational frequencies. Finally, the plan configuration which is most vulnerable and the least vulnerable to seismic loads are predicted.
\end{abstract}

Key Words:Building plan configuration, ETABS,Fundamental time period, Base shear, Storey drift, Lateral displacement.

\section{INTRODUCTION}

In the past few decades, major portion of urban infrastructure in India are delineated by buildings with complex and irregular configuration, as the focus is on aesthetic appeal and utilization of limited space. Buildings with such irregular configuration, due to their eccentricities in the centre of mass and centre of stiffness, aggravate the vulnerability of the structures response to seismic excitations. The damages incurred could be diverse from minor non structural damages to complete collapse, which necessitates the effective mitigation of this disastrous effect on human life.

Delhi being the only major city classified under seismic zone IV by IS 1893 (Part1): 2002, which houses over 25 million people as of 2015 , is having $80 \%$ of its infrastructure which will not withstand an earthquake tremor. The condition will be the same in other major cities as well if they experience an earthquake. Moreover, the number of mid rise and high rise buildings has increased as the horizontal expansions have reached a degree of saturation emphasising the need to grow vertically [3].

The seismic ground motion can affect a building in any direction. The seismic forces developed as a result will be distributed along the building height. Therefore, the building

should be designed adequately ensuring compatibility between architectural and structural aspects of design, taking into consideration the seismic design philosophies.
Most of the buildings constructed nowadays tend to have plan irregular configurations. The possible reason for undesired seismic behaviour of buildings with plan irregular configurations is the concentration of stress in a few lateral load resisting members of the structure. This is caused by localised deformations [13] combined with torsion.

Usually for architecture space planning flexibility, Moment resisting frames are adopted which resists the earthquake forces primarily by flexure [10]. Each type of plan configuration behaves differently to a seismic excitation even if it is designed as special moment resisting frame. Thus awareness is required amongst architects and engineers to select a plan configuration which undergoes minimal damage during an earthquake, avoiding economic risk during construction by providing seismic damage control measures.

\subsection{Asymmetric Plan Of Buildings}

The structural irregularity of a building could be classified broadly as plan (Horizontal)irregularity and vertical irregularity as shown in Figure1. 


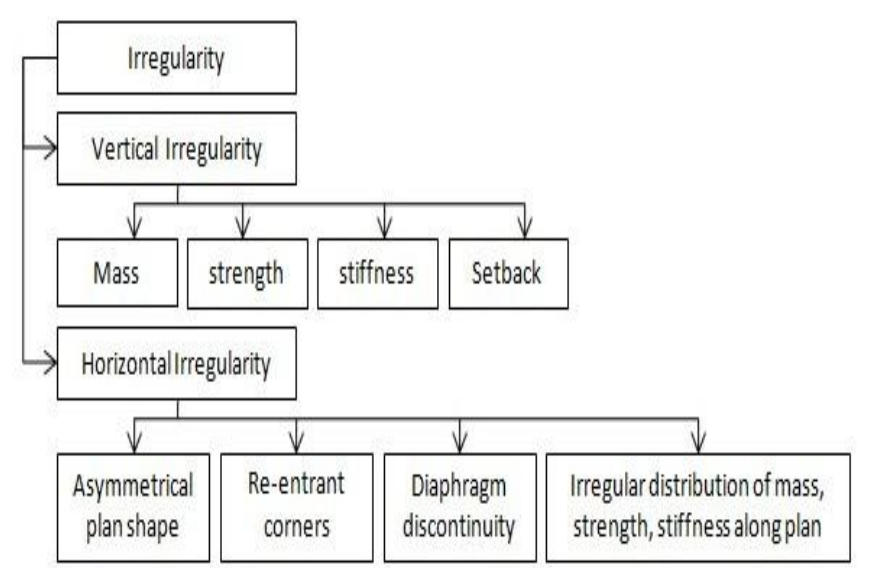

Fig-1: Flow chart showing different types of structural irregularities

A plan asymmetry in building would result in the seismic response to be both translational and rotational in nature. This is caused due to the non coinciding centres of mass and/or stiffness. The plan asymmetry could cause severe damages to structure especially at locations where the lateral flexibility is high. The Indian code IS 1893 (Part 1): 2002 prescribes the irregularity limits for buildings with reentrant corner, tensional irregularity and diaphragm discontinuity as shown inTable1.1 [16].

Table-1: Plan irregularity limits

\begin{tabular}{|l|l|l|}
\hline Irregularity & Limit & Description \\
\hline $\begin{array}{l}\text { Re-entrant } \\
\text { Corners }\end{array}$ & $R_{i} \leq 15 \%$ & $\begin{array}{l}R_{i}-\text { Projection limit of re- } \\
\text { entrant corner. }\end{array}$ \\
\hline $\begin{array}{l}\text { Torsional } \\
\text { irregularity }\end{array}$ & $\begin{array}{l}d_{\max } \leq \\
\text { computed at a particular } \\
\text { storey level. } \\
d_{\text {avg }}-\text { Average of drifts } \\
\text { computed at both sides of a } \\
\text { structure. }\end{array}$ \\
\hline $\begin{array}{l}\text { Diaphragm } \\
\text { Discontinuity }\end{array}$ & $\begin{array}{l}O_{a}> \\
S_{d s t}>\end{array}$ & $\begin{array}{l}O_{a}-\text { Open area in } \\
\text { diaphragm. } \\
S_{d s t}-\text { Diaphragm stiffness. }\end{array}$ \\
\hline
\end{tabular}

\section{LITERATURE REVIEW}

S Monish, S Karuna [2015], studied the effect of plan irregularities such as diaphragm discontinuity and re-entrant corners. Seven models each having 20 storeys was analyzed using the finite element software ETABS. Both static and dynamic analyses were carried out. The first model was a symmetrical square shaped model, three diaphragm discontinuous models with $\mathrm{H}, \mathrm{C}$, + shaped opening and the last three models having re- entrant corners with $40 \%, 60 \%$, $80 \%$ projection in $\mathrm{X}$ direction and $40 \%$ projection in $\mathrm{Y}$ direction kept constant. The authors, from the results concluded that the model with re-entrant corner with $80 \%$ projection was the most vulnerable model.

Arvindreddy, R.J.Fernandes [2015], studied the effect of regular and irregular framed structures with 15 storeys when subjected to Earthquake forces. The structures were analysed using Time history method, equivalent static method, response spectrum method and pushover method using ETABS software. A total of six models with symmetry, re-entrant corner, diaphragm discontinuity, irregular mass, torsion and stiffness were created. The earthquake was found to be more enhanced in stiffness irregular structure. So in overall it can be concluded that structure built-in with stiffness irregularity will be on non conservative side.

Shreyasvi C, B. Shivakumaraswamy [2015], taking into consideration those Buildings with re - entrant corner that are commonly encountered, have focused on studying the response of the building with a re-entrant corner located in seismic zones listed in the codes. Two building models with ground and four upper stories were considered; one of the building models had a re - entrant corner and another had regular plan configuration. Re-entrant corner projections were varied as $42.85 \%, 23.2 \%$ and $50 \%$. The modal time periods obtained from response spectrum analysis implicates that the regular buildings have longer time periods than buildings with re-entrant corner. Re - entrant buildings underwent larger displacements and drifts when compared with regular buildings.

Mohod M. V [2015], aimed at studying and understanding the critical behaviour of plan irregular structures which were subjected to seismic excitation. Lateral displacement, storey drift, base shear, storey displacement were the key parameters to ascertain the performance point of the 9 models that were modelled in ETABS software for the research. The plan irregularities adopted were as followsRegular Square Shape, T-Shape, Plus (+) Shape, E-Shape, L-Shape, Square with Core, H-Shape, C-Shape and Rectangle with core. Among the models L-shaped and Cshaped models showed larger drift than other plan irregular models.

Ahmed J and Raza S. A [2014], for the study on seismic analysis of buildings with plan irregularity selected models with rectangular shape, $Y$ shape and diaphragm discontinuity. Using the software ETABS both static and dynamic analysis methods were performed. The models had 10 storeys. Base shear and displacement were assessed. The base shear for rectangular model was greater than other two models, while the point displacement was greater for diaphragm discontinuous model due to the opening at the centre. Finally the research was concluded with the statement that rectangular model is vulnerable to seismic effect than the diaphragm discontinuous model and ' $\mathrm{Y}$ ' shaped model.

\section{ANALYTICAL PROGRAM}

Earthquake manifests as ground shaking which is caused by the sudden release of strain energy within the crust of the earth [1]. All the studies and investigations in the field of earthquake engineering repeatedly reaffirm that building with asymmetry suffers excessive damage than their asymmetric counterparts [9]. To contribute to earthquake engineering field a study is undertaken in this research to 
reckon a plan asymmetric model that does not perform adequately during an earthquake. Based on various studies carried out in the area of performance of asymmetric models during earthquake; eight models are adopted for the analysis. The models are analysed using the aid of finite element software ETABS taking into consideration the code provisions for the modelling. The analysis was performed using equivalent static analysis and response spectrum analysis. The parameters for comparison were modal mass participation factor, lateral displacement, storey drift and base shear. The models were validated to check the adequacy of software generated models.

\subsection{Modelling}

- Eight models with one symmetric model and remaining seven being asymmetric were created. All the models were having sixteen storeys (Ground +15 ). The building is located in seismic zone IV on a site with medium soil.

- All the models do not have slab at plinth level. At plinth level beams were provided connecting all columns to provide lateral stiffness and reduce the effect of soft storey.

- The wall loads were applied as superimposed dead load. The wall loads were not provided in the ground floor. No balconies were provided for the purpose of simplicity.

- $\quad$ For columns M30 grade concrete was used while M25 was used for beams and slabs.

- $\quad$ Sizes of every structural member remain constant and the size of column is not varied with the building height.

- $\quad$ Preliminary sizes of structural members were assumed by experience.

- For analysis purpose, the beams were assumed to be rectangular so as to distribute slightly larger moment in columns. Seismic loads will be considered acting in the horizontal direction (along either of the two Principal directions) and not along the vertical direction, since it was considered to be least significant.

Table-2:General building data

\begin{tabular}{|l|l|}
\hline \multicolumn{2}{|l|}{ General building Data } \\
\hline Property & $\mathrm{G}+15$ \\
\hline Floors & $0.3 \times 0.45$ \\
\hline Beam size, $\mathrm{b}_{\mathrm{b}} * \mathrm{D}_{\mathrm{b}}(\mathrm{m})$ & $4 \times 4$ \\
\hline Slab size, $\mathrm{L}_{\mathrm{s}} \mathrm{B}_{\mathrm{s}}(\mathrm{m})$ & $0.3 \times 0.9$ \\
\hline column size, $\mathrm{b}_{\mathrm{c}}{ }^{\mathrm{D}} \mathrm{D}_{\mathrm{c}}(\mathrm{m})$ & 4 \\
\hline Beam length, $\mathrm{L}_{\mathrm{b}}(\mathrm{m})$ & 0.2 \\
\hline Wall thickness, $\mathrm{t}_{\mathrm{w}}(\mathrm{m})$ & 3 \\
\hline Storey Height $(\mathrm{regular}), \mathrm{h}_{\mathrm{r}}(\mathrm{m})$ & 2 \\
\hline Foundation depth, $\mathrm{h}_{\mathrm{b}}(\mathrm{m})$ & 4 \\
\hline Storey Height $(\mathrm{ground}$ floor $), \mathrm{h}_{\mathrm{g}}(\mathrm{m})$ & 1.2 \\
\hline Parapet Height, $\mathrm{h}_{\mathrm{p}}(\mathrm{m})$ & 0.15 \\
\hline slabs depth, $\mathrm{D}_{\mathrm{s}}(\mathrm{m})$ & \\
\hline
\end{tabular}

\begin{tabular}{|l|l|} 
Height of the building, $\mathrm{H}(\mathrm{m})$ & 49 \\
\hline Brick density, $\int_{\mathrm{b}}\left(\mathrm{KN} / \mathrm{m}^{3}\right)$ & 19 \\
\hline RCC density, $\int_{\mathrm{c}}\left(\mathrm{KN} / \mathrm{m}^{3}\right)$ & 25 \\
\hline Concrete grade, $\mathrm{f}_{\mathrm{ck}}($ column$) \mathrm{MPa}$ & 30 \\
\hline Concrete grade, $\mathrm{f}_{\mathrm{ck}}(\mathrm{beams}, \mathrm{slabs}) \mathrm{MPa}$ & 25 \\
\hline Steel HYSD, $\mathrm{f}_{\mathrm{y}} \mathrm{MPa}$ & 500 \\
\hline Live load- slab, $\mathrm{W}_{\mathrm{LS}}\left(\mathrm{KN} / \mathrm{m}^{2}\right)$ & 3 \\
\hline Live load- terrace, $\mathrm{W}_{\mathrm{LT}}\left(\mathrm{KN} / \mathrm{m}^{2}\right)$ & 2 \\
\hline Floor Finish, $\mathrm{W}_{\mathrm{SS}}\left(\mathrm{KN} / \mathrm{m}^{2}\right)$ & 1 \\
\hline Floor Finish - terrace, $\mathrm{W}_{\mathrm{ST}}\left(\mathrm{KN} / \mathrm{m}^{2}\right)$ & 2 \\
\hline
\end{tabular}

Table-3:IS Code data

\begin{tabular}{|l|l|}
\hline \multicolumn{2}{|l|}{ IS code data } \\
\hline Property & Delhi \\
\hline Location & $\begin{array}{l}\text { IS1893 (Part1): } \\
2002\end{array}$ \\
\hline Earthquake load & 0.24 \\
\hline zone factor Z & 1 \\
\hline Importance factor I & 5 \\
\hline Reduction factor R & II \\
\hline soil type & $25 \%$ \\
\hline $\begin{array}{l}\text { Live load contributed to seismic } \\
\text { weight }\end{array}$ & \\
\hline
\end{tabular}

Table- 4: Storey data

\begin{tabular}{|l|l|l|}
\hline Name & $\begin{array}{l}\text { Height } \\
\mathrm{mm}\end{array}$ & $\begin{array}{l}\text { Elevation } \\
\mathrm{mm}\end{array}$ \\
\hline Story17 & 3 & 51 \\
\hline Story16 & 3 & 48 \\
\hline Story15 & 3 & 45 \\
\hline Story14 & 3 & 42 \\
\hline Story13 & 3 & 39 \\
\hline Story12 & 3 & 36 \\
\hline Story11 & 3 & 33 \\
\hline Story10 & 3 & 30 \\
\hline Story9 & 3 & 27 \\
\hline Story8 & 3 & 24 \\
\hline Story7 & 3 & 21 \\
\hline Story6 & 3 & 18 \\
\hline Story5 & 3 & 15 \\
\hline Story4 & 3 & 12 \\
\hline Story3 & 3 & 9 \\
\hline Story2 & 4 & 6 \\
\hline Story1 & 2 & 2 \\
\hline Base & 0 & \\
\hline & & 3 \\
\hline
\end{tabular}




\subsection{Model Geometry}

a) Model 1: Rectangular shaped. This model will be represented as M1.

b) Model 2: Plus shaped. The percentage projection in $\mathrm{X}$ and $\mathrm{Y}$ direction is $67 \%$. This model will be represented as M2.

c) Model 3: L shaped. The percentage projection is $57 \%$ in $\mathrm{X}$ direction and $50 \%$ in $\mathrm{Y}$ direction. This model will be represented as $\mathrm{M} 3$.

d) Model 4: rectangle with diaphragm opening. The percentage opening is $29 \%$. This model will be represented as M4.

e) Model 5: $\mathrm{T}$ shaped. The percentage projection is $57 \%$ in $\mathrm{X}$ direction and $50 \%$ in $\mathrm{Y}$ direction. This model will be represented as M5.

f) Model 6: I shaped. The percentage projection is $67 \%$ in $\mathrm{X}$ direction. This model will be represented as M6.

g) Model 7:Z shaped. The percentage projection is $57 \%$ in $\mathrm{X}$ direction. This model will be represented as M7.

h) Model 8: U Shaped. The percentage projection is $67 \%$ in Y direction. This model will be represented as M8.

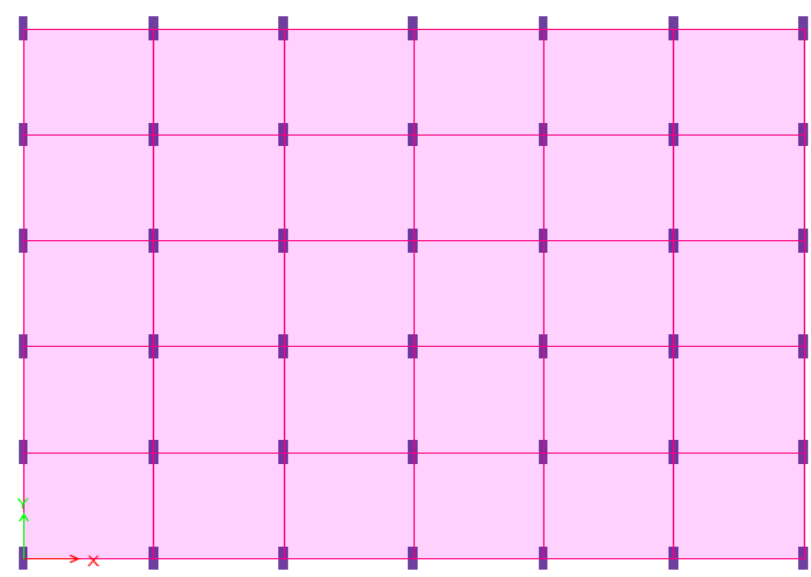

Fig- 2: Model 1( Rectangular Shaped)

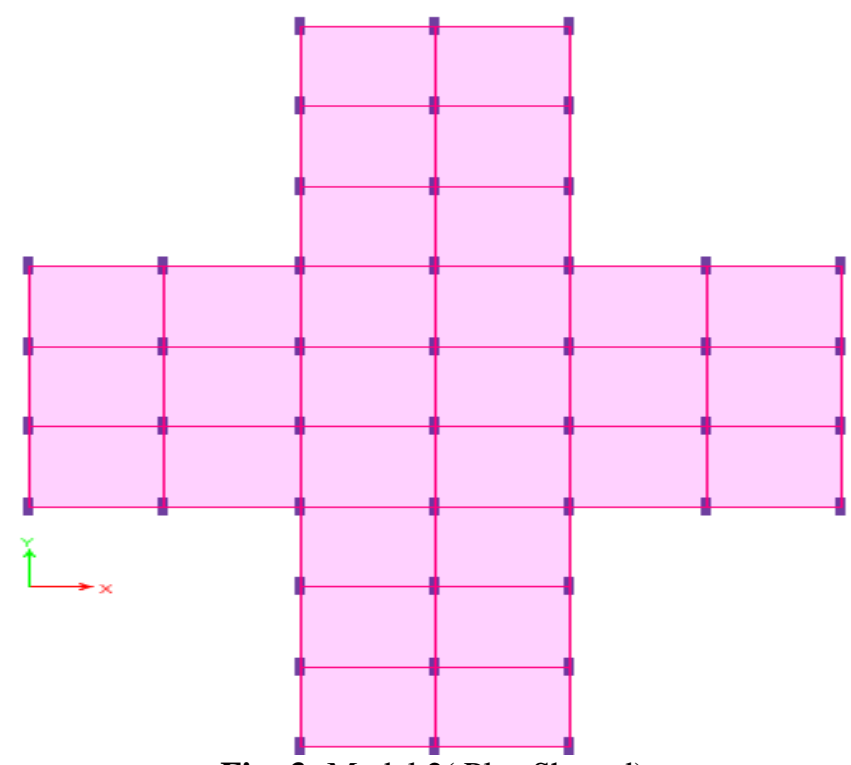

Fig- 3: Model 2( Plus Shaped)

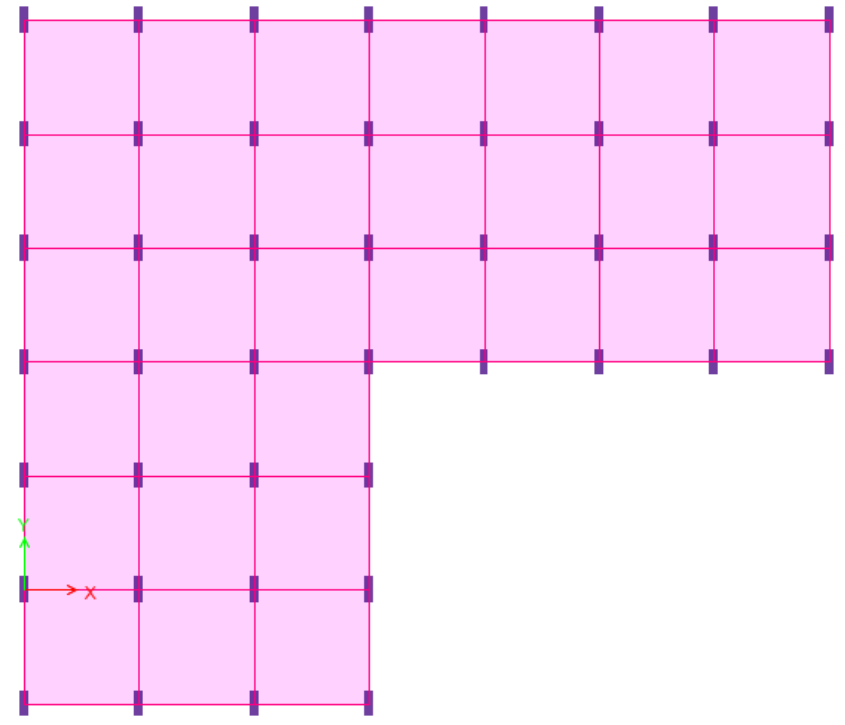

Fig- 4: Model 3: L Shaped

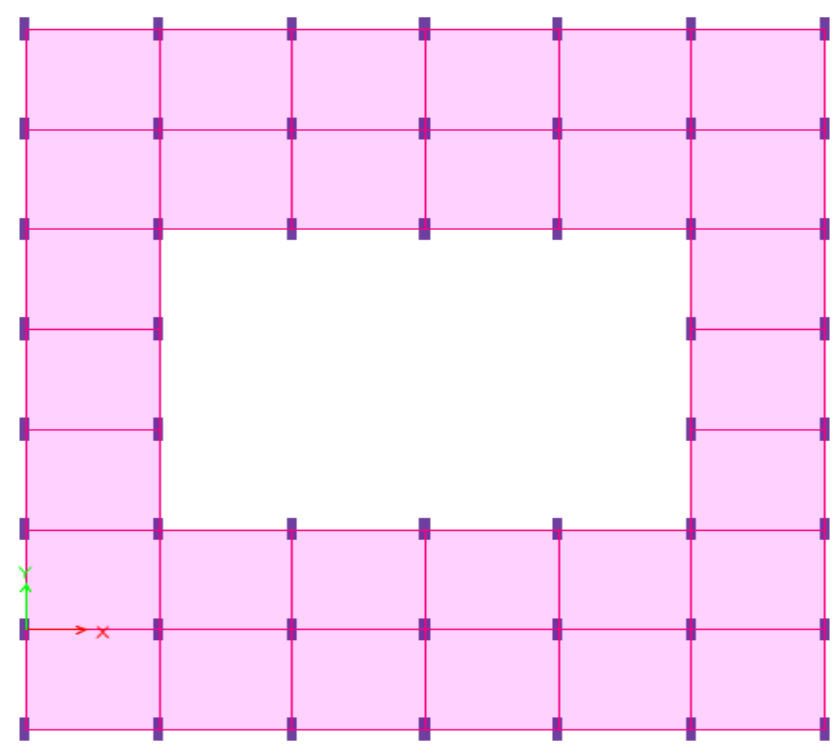

Fig- 5: Model 4: Rectangle with Opening

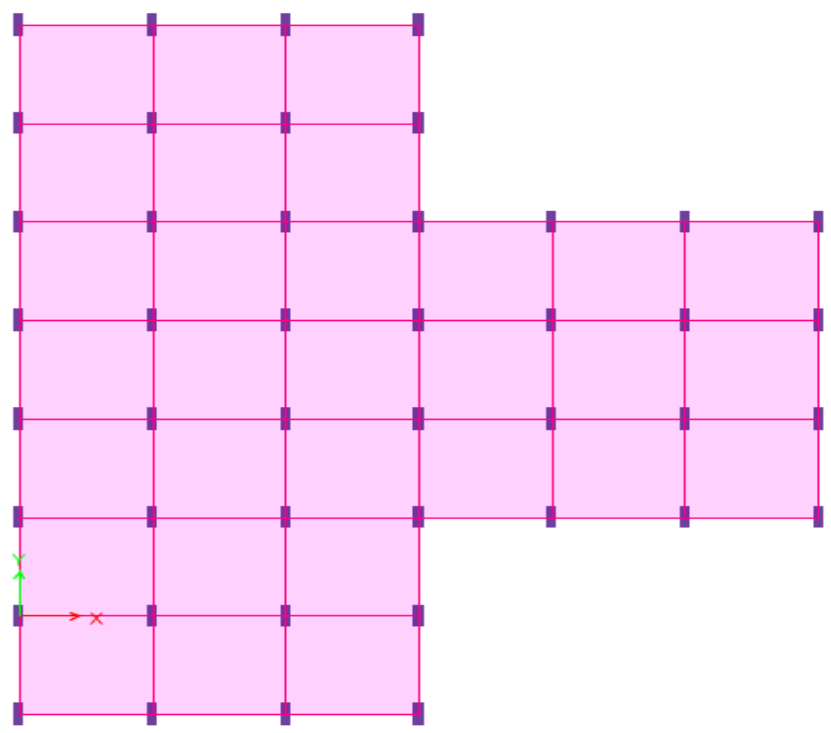

Fig- 6: Model 5: T Shaped 


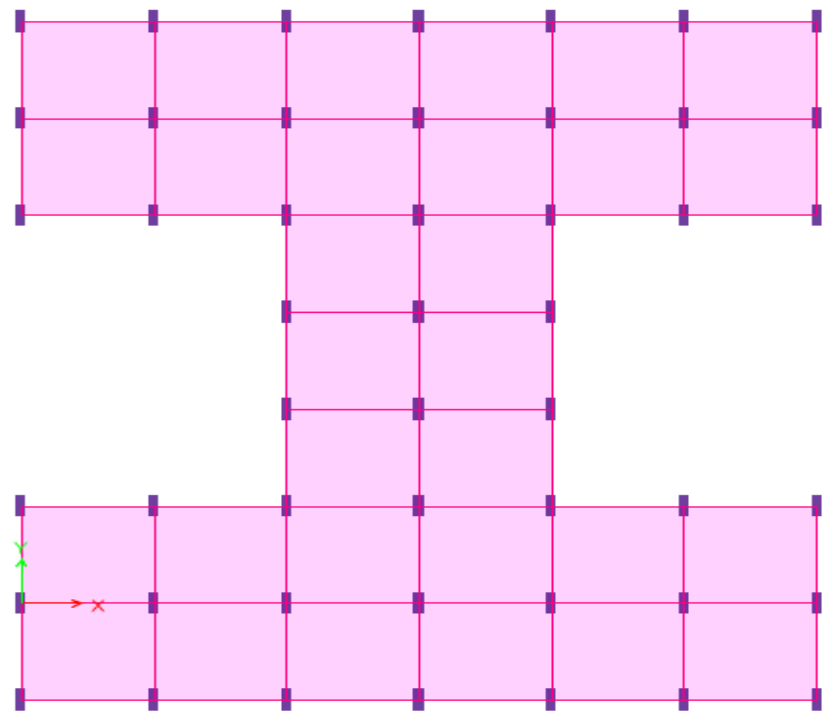

Fig- 7: Model 6(I Shaped)

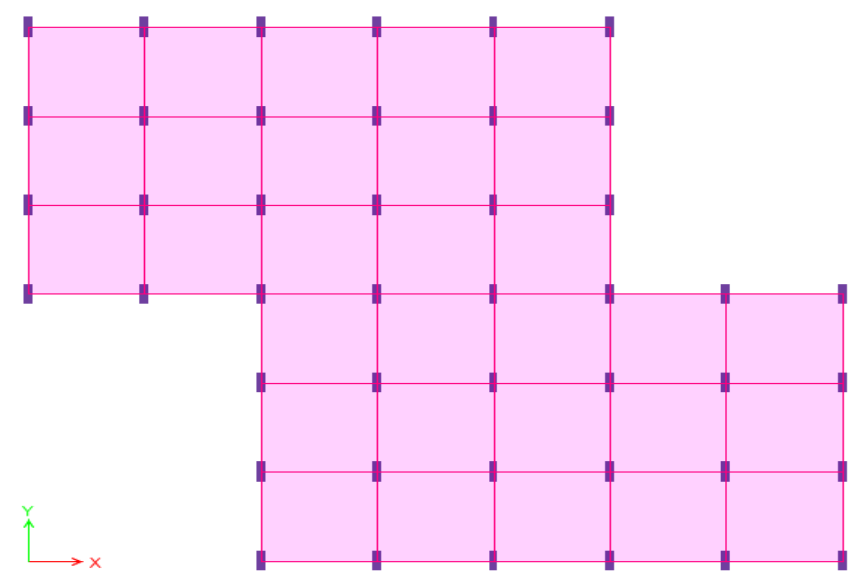

Fig - 8: Model 7(Z Shaped)

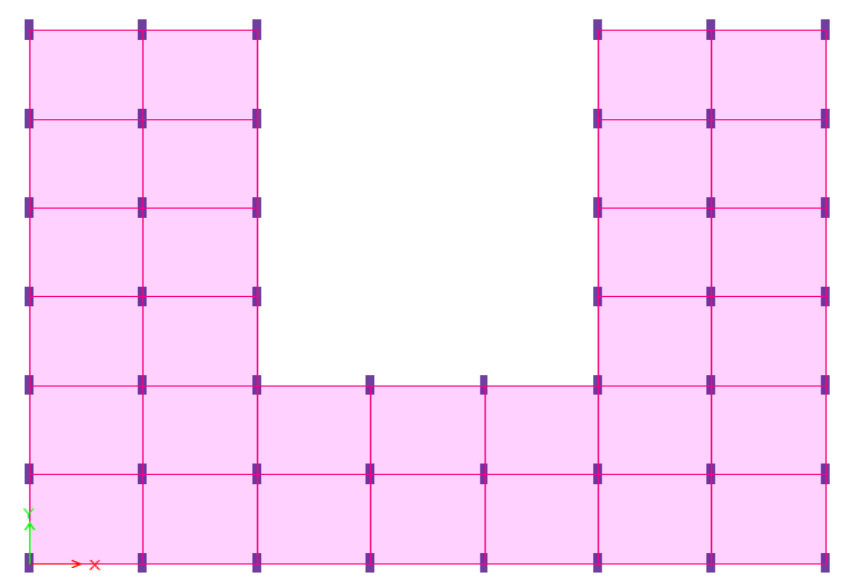

Fig- 9: Model 8(U Shaped)

\subsection{Analysis Of The Building}

As the structural models are created, the seismic forces that will be induced on the building can be determined by adopting various analysis techniques, whose degree of accuracy and the type of analytical approach vary. A building could be analyzed during linear methods and non linear methods. In the current research linear methods of analyses are adopted. The two linear methods namely equivalent lateral force method and response spectrum methods is briefly explained as below:

\section{a) Equivalent static method of analysis:}

In this the analysis will be based on the assumption that the lateral (horizontal) force acting on the building is equivalent to the dynamic force. The method is conservative and useful for analyzing simple symmetric building. The base shear that would be calculated using code provisions will be distributed along the building height. The analysis can be performed by defining parameters like fundamental time period of vibration, soil conditions, mode shape for the time period chosen and factors necessary for determining the horizontal seismic coefficient using clause 6.4 of IS 1893 (Part 1): 2002.

\section{b) Response spectrum methods of analysis:}

If the building is assumed to be affected by time period apart from fundamental time period then response spectrum methods are adopted. The response spectra will be used which is given in clause 6.4 .5 of IS 1893 (Part 1): 2002 which depends on the three different soil sites. This method is recommended for irregular buildings which are framed and the height is greater than $12 \mathrm{~m}$ in seismic zones IV and $\mathrm{V}$. Apart from the parameters mentioned in equivalent static method, the other parameter to be determined is the modes determined by performing a modal analysis. The number of modes is selected based on clause 7.8.4.3 of IS 1893 (Part 1): 2002. After this is established the peak response would be computed using Square Root of Some of Squares (SRSS) Sum of Absolute of Modal Response Values (ABS) and the Complete Quadratic Combination (CQC). Once the methods are applied the base shear $\left(\mathrm{V}_{\mathrm{BR}}\right)$ obtained from Response spectrum methods need to be scaled in accordance with the once determined using Equivalent static method $\left(\mathrm{V}_{\mathrm{EQ}}\right)$ as the building asymmetry governs the scaling factor $\left(\mathrm{V}_{\mathrm{EQ}} / \mathrm{V}_{\mathrm{BR}}\right)$ so obtained.

\section{SEISMIC WEIGHT}

The seismic weight of the whole building is the sum of the seismic weights of all the floors. The seismic weight of each floor is its full dead load plus appropriate amount of imposed live load.

\section{MODESHAPES AND \\ PARTICIPATION MASS FACTORS}

MODAL

When the inertia forces are induced on a building caused by synchronous harmonic motion, they get balanced by the restoring forces within the building. The structural configurations developed for such a process results in mode shapes or Eigen vector which is determined as a non-trivial solution for a Eigen value problem in MDOF systems.

The modal participation mass factor of a mode of vibration is the amount by which that particular mode contributes to the overall vibration of the structure under horizontal and vertical earthquake ground motions as defined by code [6]. The values of modal participation mass factors obtained for a building using dynamic analysis procedures will be used to 
determine the modal mass which is significant in determining the number of modes to be used in analysis of the building as given in clause 7.8.4.2 of IS 1893 (Part 1): 2002. This criterion will be checked in the research.

\section{VALIDATION}

To check the authenticity of ETABS analyzed models, model 1 will be validated by calculating the base shear using code provisions and then compared with ETABS generated values. If the values comply with one another, then the ETABS models will be validated. From the calculations it is concluded that $\mathrm{V}_{\mathrm{B}(\mathrm{IS})} \approx \mathrm{V}_{\mathrm{B} \text { (ETABS), thus validating the ETABS }}$ analyzed model, where the values for

1. Design seismic base shear, $\mathrm{V}_{\mathrm{B}(\mathrm{IS})}=\mathrm{Ah} * \mathrm{~W}=2673.544 \mathrm{KN}$. 2. Seismic base shear from static analysis using ETABS: $\mathrm{V}_{\mathrm{B}(\mathrm{ETABS})}=2639 \mathrm{KN}$.

\section{RESULTS AND DISCUSSIONS}

\subsection{Fundamental Time Period}

It is the first longest modal time period of un-damped free vibration for a structure. Fundamental time period obtained from ETABS analysis and from code provisions are listed in Table.

Table- 5:Fundamental Time Period for different Cases

\begin{tabular}{|l|l|l|l|l|l|l|}
\hline \multirow{2}{*}{$\begin{array}{l}\text { Mod } \\
\text { els }\end{array}$} & \multicolumn{3}{|l}{ Time period (s) } \\
\cline { 2 - 7 } & $\begin{array}{l}\text { Program } \\
\text { calculated (T1) }\end{array}$ & \multicolumn{2}{ll}{$\begin{array}{l}\text { without infill } \\
\text { (T2) }\end{array}$} & \multicolumn{2}{l|}{$\begin{array}{l}\text { with infill } \\
\text { (T3) }\end{array}$} \\
\cline { 2 - 7 } & $\mathrm{X}$ & $\mathrm{Y}$ & $\mathrm{X}$ & $\mathrm{Y}$ & $\mathrm{X}$ & $\mathrm{Y}$ \\
\hline M1 & 3.45 & 3.45 & 1.389 & 1.389 & 0.9 & 0.98 \\
\hline M2 & 3.46 & 2.13 & 1.389 & 1.389 & 0.9 & $\begin{array}{l}0.73 \\
5\end{array}$ \\
\hline M3 & 3.46 & 2.1 & 1.389 & 1.389 & 0.83 & 0.9 \\
\hline M4 & 3.49 & 2.14 & 1.389 & 1.389 & 0.9 & 0.83 \\
\hline M5 & 3.45 & 2.1 & 1.389 & 1.389 & 0.9 & 0.83 \\
\hline M6 & 3.49 & 2.1 & 1.389 & 1.389 & 0.9 & 0.83 \\
\hline M7 & 3.896 & 2.83 & 1.389 & 1.389 & 0.83 & 0.9 \\
\hline M8 & 3.47 & 2.14 & 1.389 & 1.389 & 0.83 & 0.9 \\
\hline
\end{tabular}

\subsection{Base Shear}

Base shear is the total design lateral force along any principal direction of a structure. This is the maximum lateral force which occurs at the base of a structure.

Table-6: Base shear for Response Spectrum Analysis after applying Scale Factors

\begin{tabular}{|l|l|l|l|l|l|l|}
\hline \multicolumn{6}{|c|}{ Base Shear (KN) } \\
\hline $\begin{array}{l}\text { Mo } \\
\text { del }\end{array}$ & $\begin{array}{l}\text { RSX- } \\
\text { T1 }\end{array}$ & $\begin{array}{l}\text { RSY- } \\
\text { T1 }\end{array}$ & $\begin{array}{l}\text { RSX- } \\
\text { T2 }\end{array}$ & $\begin{array}{l}\text { RSY- } \\
\text { T2 }\end{array}$ & $\begin{array}{l}\text { RSX- } \\
\text { T3 }\end{array}$ & $\begin{array}{l}\text { RSY- } \\
\text { T3 }\end{array}$ \\
\hline M1 & 1214 & 1557 & 2633 & 2642 & 4073 & 3734 \\
\hline M2 & 1244 & 1690 & 2742 & 2744 & 4262 & 5191 \\
\hline M3 & 1242 & 1610 & 2691 & 2691 & 4485 & 4136 \\
\hline M4 & 1340 & 1731 & 2867 & 2875 & 4430 & 4788 \\
\hline
\end{tabular}

\begin{tabular}{|l|l|l|l|l|l|l|} 
M5 & 1230 & 1502 & 2688 & 2574 & 4157 & 4290 \\
\hline M6 & 1324 & 1633 & 2795 & 2799 & 4316 & 4666 \\
\hline M7 & 1244 & 1585 & 2696 & 2686 & 4493 & 4154 \\
\hline M8 & 1263 & 1712 & 2806 & 2799 & 4664 & 4319 \\
\hline
\end{tabular}

\subsection{Modal Participation mass Factor}

The mass participation factors in the translational direction $\mathrm{X}$ and $\mathrm{Y}$ and in rotational direction.

Table-7: Modal participation mass factor (sum of 20 modes)

\begin{tabular}{|l|l|l|l|}
\hline \multicolumn{4}{|c|}{ Modal participation mass factor \% (sum of 20 modes) } \\
\hline Model & Sum RX & Sum RY & Sum RZ \\
\hline M1 & 92.1 & 96.01 & 98.25 \\
\hline M2 & 92 & 95.91 & 98.25 \\
\hline M3 & 92 & 95.9 & 98.23 \\
\hline M4 & 91.8 & 95.8 & 98.27 \\
\hline M5 & 92.05 & 95.9 & 98.24 \\
\hline M6 & 91.8 & 95.8 & 98.25 \\
\hline M7 & 92 & 95.9 & 98.23 \\
\hline M8 & 92.9 & 95.8 & 98.23 \\
\hline
\end{tabular}

\subsection{Rotational Frequency}

Since the Modal participation mass factor are similar for T1, $\mathrm{T} 2$ and $\mathrm{T} 3$, the rotational frequencies corresponding to $\mathrm{T} 2$ are only listed for the 20 modes considered. Rotational frequencies as obtained from ETABS for 20 modes are listed in table.

Table- 8: Rotational Frequency $(\mathrm{Hz})$

\begin{tabular}{|l|l|l|l|l|l|l|l|l|}
\hline \multirow{2}{*}{$\begin{array}{l}\text { Mod } \\
\text { e }\end{array}$} & \multicolumn{6}{|l|}{ Rotational Frequency $(\mathrm{Hz})$} \\
\cline { 2 - 9 } & M1 & M2 & M3 & M4 & M5 & M6 & M7 & M8 \\
\hline 2 & 2.1 & 2.0 & 2.1 & 2.1 & 2.1 & 2.1 & 2.1 & 2.0 \\
\hline 3 & 2.7 & 2.4 & 2.6 & 2.6 & 2.6 & 2.5 & 2.6 & 2.7 \\
\hline 4 & 2.7 & 2.8 & 2.7 & 2.7 & 2.7 & 2.6 & 2.7 & 2.8 \\
\hline 5 & 6.3 & 6.2 & 6.3 & 6.4 & 6.3 & 6.5 & 6.3 & 6.2 \\
\hline 6 & 8.4 & 7.5 & 8.1 & 8.1 & 8.0 & 7.6 & 8.1 & 8.4 \\
\hline 7 & 10. & 10.7 & 8.5 & 8.6 & 8.6 & 8.3 & 8.4 & 8.7 \\
\hline \multirow{2}{*}{8} & 8 & 8 & 9 & 11. & 10. & 11. & 10. & 10. \\
& 14. & 13. & 14. & 14. & 14. & 13. & 14. & 14. \\
\hline 9 & 15. & 15. & 15. & 15. & 15. & 15. & 15. & 15. \\
\hline \multirow{2}{*}{10} & 2 & 5 & 4 & 7 & 5 & 3 & 3 & 6 \\
\hline \multirow{2}{*}{11} & 5. & 15. & 15. & 15. & 15. & 16. & 15. & 15. \\
& 5 & 7 & 6 & 9 & 5 & 0 & 6 & 8 \\
\hline \multirow{2}{*}{12} & 22. & 20. & 20. & 21. & 20. & 20. & 20. & 20. \\
& 2 & 4 & 9 & 0 & 1 & 1 & 4 & 4 \\
\hline 13 & 23. & 24. & 23. & 24. & 23. & 23. & 23. & 24. \\
\hline & & & & & & & & 6 \\
\hline
\end{tabular}




\begin{tabular}{|l|l|l|l|l|l|l|l|l|} 
& 2 & 0 & 4 & 0 & 6 & 5 & 4 & 1 \\
\hline \multirow{2}{*}{14} & 25. & 25. & 25. & 26. & 25. & 26. & 25. & 25. \\
& 6 & 7 & 9 & 3 & 7 & 4 & 9 & 9 \\
\hline \multirow{2}{*}{15} & 30. & 27. & 30. & 28. & 29. & 27. & 29. & 31. \\
& 7 & 0 & 4 & 9 & 1 & 6 & 7 & 0 \\
\hline \multirow{2}{*}{16} & 31. & 31. & 31. & 32. & 31. & 32. & 31. & 31. \\
& 1 & 2 & 3 & 0 & 1 & 0 & 3 & 4 \\
\hline \multirow{2}{*}{17} & 32. & 33. & 33. & 33. & 33. & 33. & 33. & 34. \\
& 8 & 8 & 1 & 9 & 3 & 4 & 1 & 1 \\
\hline \multirow{2}{*}{18} & 36. & 35. & 37. & 37. & 36. & 36. & 37. & 37. \\
& 7 & 3 & 0 & 8 & 8 & 2 & 1 & 3 \\
\hline \multirow{2}{*}{19} & 40. & 36. & 40. & 37. & 38. & 37. & 39. & 41. \\
& 6 & 9 & 3 & 9 & 3 & 9 & 2 & 1 \\
\hline \multirow{2}{*}{20} & 42. & 42. & 42. & 43. & 42. & 43. & 42. & 43. \\
& 5 & 9 & 9 & 9 & 7 & 9 & 9 & 3 \\
\hline
\end{tabular}

Table- 10: Drift (m) for Time Period T1, T2, T3 in Y direction

\begin{tabular}{|l|l|l|l|l|}
\hline \multicolumn{5}{|c|}{ Drift (m) for Time Period T1, T2, T3 in Y direction } \\
\hline Model & T1 & T2 & T3 & $\begin{array}{l}0.004 \mathrm{H} \\
(\mathrm{H}=49 \mathrm{~m})\end{array}$ \\
\hline M1 & 0.00081 & 0.00138 & 0.00195 & 0.016 \\
\hline M2 & 0.00079 & 0.00128 & 0.00242 & 0.016 \\
\hline M3 & 0.00127 & 0.00210 & 0.00323 & 0.016 \\
\hline M4 & 0.00079 & 0.00131 & 0.00219 & 0.016 \\
\hline M5 & 0.00104 & 0.00171 & 0.00285 & 0.016 \\
\hline M6 & 0.00081 & 0.00138 & 0.00231 & 0.016 \\
\hline M7 & 0.00080 & 0.00137 & 0.00211 & 0.016 \\
\hline M8 & 0.00078 & 0.00128 & 0.00197 & 0.016 \\
\hline
\end{tabular}

\subsection{Storey Drift}

The displacement of one level relative to the other level above or below in a building is called storey drift. This drift is restricted by code to be below 0.004 times the storey height as given in clause 7.11 of IS 1893 (Part 1): 2002. The storey drift in $\mathrm{X}$ and $\mathrm{Y}$ directions are given in Table.

Table-9: Drift (m) for Time Period T1, T2, and T3 in X direction

\begin{tabular}{|l|l|l|l|l|}
\hline \multicolumn{5}{|c|}{ Drift (m) for Time Period T1, T2, T3 in X direction } \\
\hline $\begin{array}{l}\text { Mode } \\
1\end{array}$ & $\mathrm{~T} 1$ & $\mathrm{~T} 2$ & $\mathrm{~T} 3$ & $\begin{array}{l}0.004 \mathrm{H} \\
(\mathrm{H}=4 \mathrm{~m})\end{array}$ \\
\hline M1 & $\begin{array}{l}0.0013 \\
4\end{array}$ & $\begin{array}{l}0.00290 \\
5\end{array}$ & $\begin{array}{l}0.00449 \\
4\end{array}$ & 0.016 \\
\hline M2 & $\begin{array}{l}0.0013 \\
2\end{array}$ & $\begin{array}{l}0.00290 \\
8\end{array}$ & $\begin{array}{l}0.00449 \\
2\end{array}$ & 0.016 \\
\hline M3 & $\begin{array}{l}0.0013 \\
6\end{array}$ & $\begin{array}{l}0.00294 \\
5\end{array}$ & $\begin{array}{l}0.00490 \\
9\end{array}$ & 0.016 \\
\hline M4 & $\begin{array}{l}0.0012 \\
9\end{array}$ & $\begin{array}{l}0.00275 \\
9\end{array}$ & $\begin{array}{l}0.00426 \\
7\end{array}$ & 0.016 \\
\hline M5 & $\begin{array}{l}0.0013 \\
3\end{array}$ & $\begin{array}{l}0.00290 \\
6\end{array}$ & $\begin{array}{l}0.00449 \\
1\end{array}$ & 0.016 \\
\hline M6 & $\begin{array}{l}0.0013 \\
0\end{array}$ & $\begin{array}{l}0.00274 \\
2\end{array}$ & $\begin{array}{l}0.00423 \\
9\end{array}$ & 0.016 \\
\hline M7 & $\begin{array}{l}0.0013 \\
3\end{array}$ & $\begin{array}{l}0.00286 \\
6\end{array}$ & $\begin{array}{l}0.00477 \\
9\end{array}$ & 0.016 \\
\hline M8 & $\begin{array}{l}0.0013 \\
5\end{array}$ & $\begin{array}{l}0.00298 \\
6\end{array}$ & $\begin{array}{l}0.00497 \\
6\end{array}$ & 0.016 \\
\hline
\end{tabular}

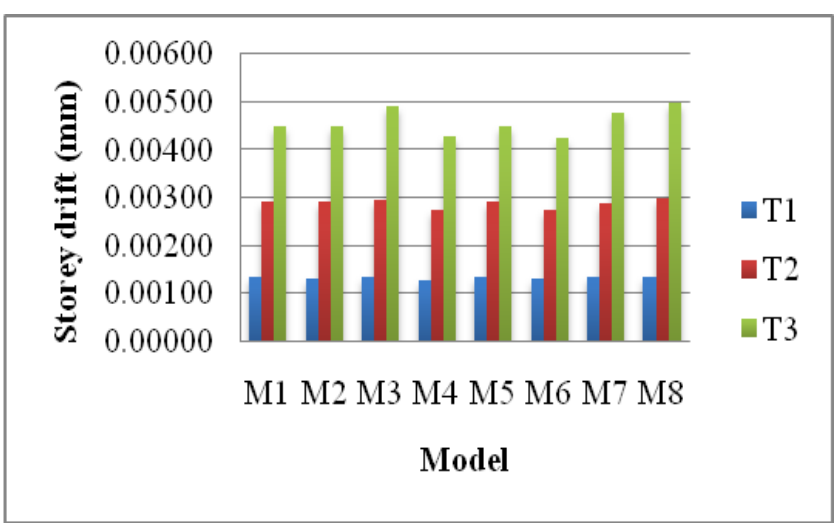

Chart-1: Maximum Storey Drift in X direction 


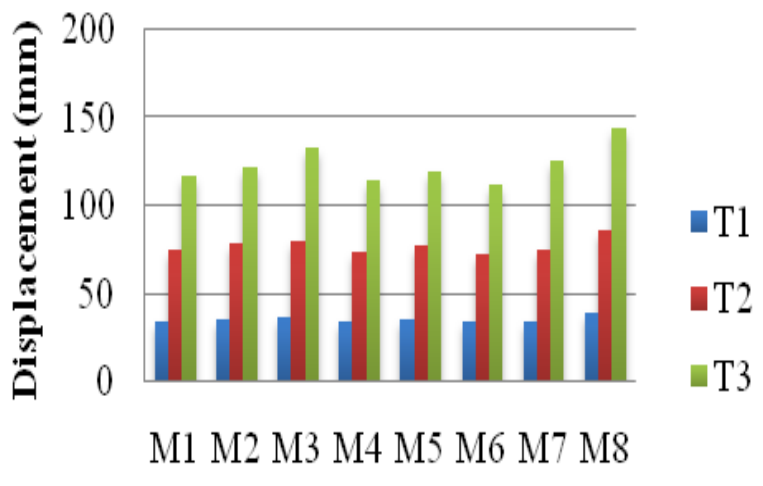

Model

Chart-3:Maximum Lateral Displacement in X Direction

Table-12: Displacement for Time Period T1, T2, T3 in Y Direction

\begin{tabular}{|l|l|l|l|}
\hline \multicolumn{4}{|l}{$\begin{array}{l}\text { displacement (mm) for various time period in Y } \\
\text { direction }\end{array}$} \\
\hline Model & T1 & T2 & T3 \\
\hline M1 & 28.2 & 47.8 & 67.6 \\
\hline M2 & 27 & 43.9 & 83.1 \\
\hline M3 & 42.7 & 70.9 & 109 \\
\hline M4 & 27.7 & 46.1 & 76.8 \\
\hline M5 & 35.2 & 58.1 & 96.8 \\
\hline M6 & 28.8 & 49.4 & 82.3 \\
\hline M7 & 28.1 & 47.7 & 73.6 \\
\hline M8 & 27 & 44.3 & 68.2 \\
\hline
\end{tabular}

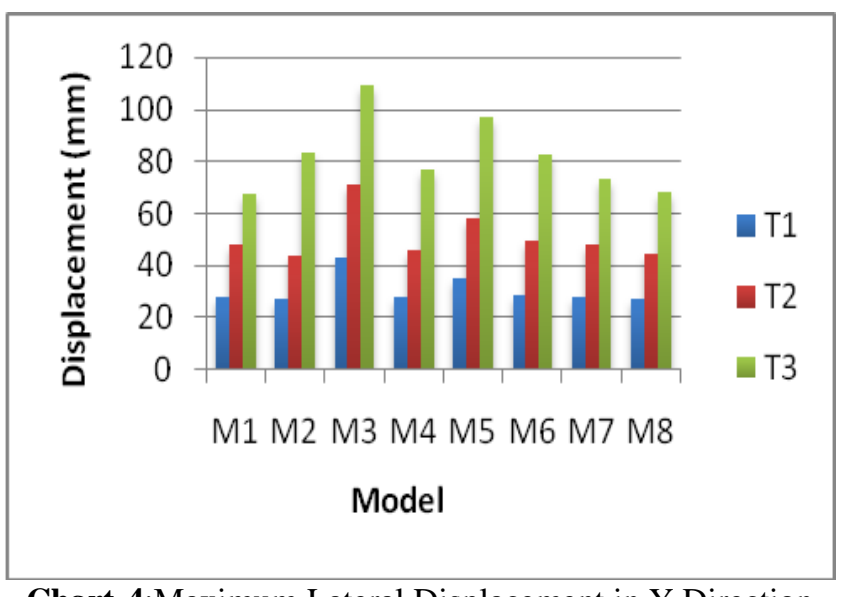

Chart-4:Maximum Lateral Displacement in Y Direction

\section{COMPARATIVE STUDY}

- $\quad$ Time period T2 is around 1.5 times greater than T3 while $\mathrm{T} 1$ is around 4 timesgreater in $\mathrm{X}$ direction than $\mathrm{T} 3$ and around 2.5 times greater in $\mathrm{Y}$ direction.

- $\quad$ For T1, base shear of M5 is $1.3 \%$ more in $\mathrm{X}$ direction and $3.53 \%$ less in Ydirection compared to M1. For M4 the base shear is increasing by $10.37 \%$ in $\mathrm{X}$ direction and $11.17 \%$ in $\mathrm{Y}$ direction as compared to M1.

- $\quad$ For T2, base shear of M5 is $2.1 \%$ more in X direction and $2.58 \%$ less in Ydirection compared to M1. For M4 the base shear is increasing by $8.8 \%$ bothin $\mathrm{X}$ and $\mathrm{Y}$ directions as compared to M1.
- $\quad$ For T3, base shear of M5 is $2 \%$ more in $\mathrm{X}$ direction but in Y direction base shear of M3 and M5 is 10.76\% and $14.89 \%$ more respectively compared to M1.

- Modal participation mass factor for all the models are greater than 90\% in translational direction and rotational direction. The values are similar for all models; translational $\mathrm{X}$ has approximately 92\%, translational $\mathrm{Y}$ has approximately $96 \%$, rotational direction has approximately $98 \%$. The frequency is beyond $33 \mathrm{~Hz}$ for modes above 18 .

- $\quad$ M4 has the least storey drift in X direction compared to all the other models. However the drifts of all the models are well within permissible limits.

- $\quad$ M8 has the least storey drift in Y direction compared to all the other models. However the drifts of all the models are well within permissible limits.

- $\quad$ For all the three cases of time periods i.e. T1, T2 and T3, the lateral displacement of M6 is found to be lesser by $1.75 \%, 4.85 \%$ and $4.84 \%$ respectively than $\mathrm{M} 1$ in $\mathrm{X}$ direction.

- $\quad$ 88 has the highest value of lateral displacement in $\mathrm{X}$ direction by $10.7 \%, 12.6 \%$ and $18.9 \%$ respectively for T1, T2 and T3.

- On the contrary, M8 is having least value of lateral displacement in Y direction.

- $\quad$ For all the three cases of time periods i.e. T1, T2 and $\mathrm{T} 3$, the lateral displacement of $\mathrm{M} 3$ is found to be higher by $33.95 \%, 32.5 \%$ and $38 \%$ respectively than $\mathrm{M} 1$ in $\mathrm{Y}$ direction.

\section{CONCLUSIONS}

The seismic analyses of eight models with varying plan configurations are performed using the aid of ETABS. The models are analysed by Equivalent static method and response spectrum methods. After the analysis and interpretation of results in the form of base shear, mass participation factor, frequency, drift and lateral displacement, the conclusions extracted are:

[1]. From the results it is evident that equivalent static method gives a higher base shear when compared to response spectrum method.

[2]. Even though the surface area of the building plan configuration is kept constant in each floor, the base shear is not same in any of the buildings as the seismic weight varies with change in building plan configuration.

[3]. From the studies it is again observed that there is huge variation in program calculated time period and the time period calculated using IS 1893 (Part 1):2002, once again emphasising that more clarity is required in calculating the time period for buildings with different plan configuration.

[4]. The base shear in $\mathrm{T}$ shaped building was least among all the models and the base shear obtained for rectangular shaped with opening was having the highest.

[5]. The buildings; rectangular shape with opening and I shaped, performs consistently better than buildings with $\mathrm{L}$ shape and $\mathrm{T}$ shape. 
[6]. From the above points it can be arrived at a broader conclusion that buildings with plan configuration which are symmetrical in both $\mathrm{X}$ and $\mathrm{Y}$ directions perform better than plan configuration which are unsymmetrical in one or both directions.

\section{REFERENCE}

[1]. A Study on Seismic Performance of High Rise Irregular RC Framed Buildings, International Research Journal of Engineering and Technology04, 2015.

[2]. Amr S. Elnashai, Luigi Di Sarno. Fundamentals of Earthquake Engineering. USA: John Wiley \& Sons, 2010.

[3]. Arvind Reddy, R. J. Fernandes. "Seismic Analysis of RC Regular and Irregular Frame Structures." (International Research Journal of Engineering and Technology) 02, no. 05 (2015).

[4]. Himanshu Gaur, R.K Goliya, Krishna Murari, Dr. A. K Mullick. "A Parametric Study of Multi- Storey RC Buildings with Horizontal Irregularity." (International Journal of Research in Engineering and Technology) 03, no. 04 (2014).

[5]. "IS : 875 ( Part 2 ) - 1987 "Code of Practice for Design Loads (Other Than Earthquake) for Buildings and Structures" Part 2, Imposed Loads." New Delhi: Bureau of Indian Standards.

[6]. "IS : 875 (Part 1) - 1987, "Code Of Practice for Design Loads (Other Than Earthquake) for Buildings and Structures" Part 1- Dead Loads - Unit Weights Of Building Materials and Stored Materials (Second Revision)." New Delhi: Bureau of Indian Standards.

[7]. [7]"IS 1893-2002(part-1), "Criteria for Earthquake Resistant Design of Structures, General Provisions and Buildings" Part 1- General Provisions and Buildings (FifthRevision)." New Delhi: Bureau of Indian Standards.

[8]. "IS 456: 2000, "Indian Standard Plain And Reinforced Concrete - Code Of Practice" (Fourth Revision)." New Delhi: Bureau Of Indian Standards.

[9]. Joheb Ahmed, Syed Ahamed Raza. "Seismic Vulnerability of RC Buildings by considering Plan Irregularities using Pushover Analysis." (Global Journal For Research Analysis) 03, no. 09 (2014).

[10]. M. R Wakchaure, Anantwad Shirish, Rohit Nikam. "Study of Plan Irregularity on High- Rise Structures." (International Journal for Innovative Research and Development) 01, no. 08 (2012.).

[11]. ]Moehle, Jack P, John D. Hooper, Chris D. Lubke. Seismic Design of Reinforced Concrete Special Moment Frames: A Guide for Practicing Engineers. National Institute of Standards and Technology, 2008.

[12]. Mohod, Milind V. "Effect of Shape and Plan Configuration on Seismic Response of Structure." (International Journal of Scientific \& Technology Research) 04, no. 09 (2015).

[13]. Motiram, Bharwani Hemlata. Earthquake Risk Assessment, Loss Estimation and Vulnerability Mapping for Dehradun City, India. dissertation thesis, Unversity of Twente, 2014.
[14]. Pankaj Agarwal, Manish Shrikhande. Earthquake Resistant Design of Structures. PHI Learners Pvt. Lt, 2014.

[15]. Ravikumar C M, Babu Narayan K S, Sujith B V, Venkat Reddy D. "Effect of Irregular Configurations on Seismic Vulnerability of RC Buildings." (Architecture Research) 2012.

[16]. S.Varadharajan "Study of Irregular RC Buildings under Seismic effect," Kurukshetra, IndiaNational Institute of Technology2014

[17]. [16]Shreyasvi C, B. Shivakumaraswamy. "Seismic Response of Buildings with Re- Entrant Corners in Different Seismic Zones." (International Journal of Research in Engineering and Technology) 04, no. 04 (2015).

[18]. Sober'on, Ra'ul Gonz'alez Herrera and Consuelo G'omez. "Influence of Plan Irregularity of Buildings." China: The 14thWorld Conference on Earthquake Engineering, 2008.

[19]. T. Mahdi, V. Soltangharaie. "Static and Dynamic Analyses of Asymmetric Reinforced Concrete Frames." Lisboa: the 15th World Conference on Earthquake Engineering, 2012. 